\title{
Transformation of Fishermen Community: From Deterministic to Rational-Instrumental Culture
}

\author{
M. Hakim \\ STIE YAPTI Jeneponto Sulawesi Selatan \\ Indonesia
}

\begin{abstract}
Generally, the fishermen community has characteristics in 'Deterministic' culture particularly in South Sulawesi. The main characteristic of 'Deterministic' culture is a believer that God is a determinant of all processes of human life, and man only 'Surrender' (fatalist) in accepting all the provisions of the Lord to him and do not even have the wellness at all. This culture is 'accused' as a ringleader 'backwardness' of the fishermen communities, especially in South Sulawesi. In that context, this paper intends to reveal the workings of 'Deterministic' culture in fishermen communities with its sociocultural implications. At the same time it is theoretically described strategic efforts by policy makers to create the social conditions for the fishermen communities in order creating a 'Rational-instrumental' culture as the antithesis of the 'Deterministic' culture. 'Rational-instrumental' culture in question believed that Nothing Impossible 'in this world as long as people continue to strive and struggle by relying on reasoning and thought.This paper is based on research on fishermen communities in South Sulawesi. Using a case study approach, the data collected with the depth-interviews, technique with 5 fishermen as an informant. The results showed that in the deterministic culture of fishermen communities is the result of the historical construction of local beliefs with the teachings of the Sufi in Islam. As compensation, it takes the intervention of all parties in strengthening the condition of 'Rationalinstrumental' culture as a means of improving the welfare of the fishermen community.
\end{abstract}

Keywords: fishermen community, deterministic, rationalinstrumental, transformation.

\section{INTRODUCTION}

Poverty and social-economic inequality of fishermen community caused by the actions of exploitation of capital owners to fishermen of workers and also caused by the impact of the blue revolution structurally as the main course, while at the fisherman workers caused by underdevelopment of instrumental values culturally as the second case. ${ }^{(1)}$

Less the development of instrumental values to part of fishermen working as one of the causes result in low productivity, dependence, and consumerism of the fishermen. Moreover, underdevelopment of instrumental values for some fishermen workers formed through a long historical process, derived from the teachings of Sufiism which in its development organized in the form of institutes, namely the Khalawatiyah Order, among others: (1) dependence on the absolute will of God is done by constructing an attitude of 'tawakkal' or resignation (surrender to fate and destiny) and pleasure (willingly accept 'qadha' and 'qadhar'; (2) waiver of world affairs conducted by prioritizing the fulfillment of 'Nafs Mutmainnah' and control the 'nafs ammarah' and 'lawwamah' and constructing attitudes: the 'zuhud' or ascetic (distance themselves from the affairs of the world), 'qanaah' (limiting love of the world), 'uzlah' or solitude (avoid the crowds); and (3) 'dzikir' or remembrance as only the most effective way than the effort or activity in the fulfillment of the purposes of life. (2) This aspect of cultural impact on individual workers in the form of weak fishermen instrumental values undermined attitudes and behavior that is characterized by a strong feeling of marginality such as: the attitude of apathist; fatalism or resignation to fate, depending wasteful because sufiisme growing influence since medieval times. ${ }^{(3)}$

Based on the above, it is important and urgent to transform into social and cultural in the fishing community. One of the actions that can be done is conditioning a cultural shift from deterministic toward rational-instrumental culture.

\section{CONDITIONS OF SOCIAL TRANSFORMATION OF FISHERMEN}

As a community, fishermen community should be convinced that poverty is not a fate, it can be improved through hard work. ${ }^{(4)}$ Work is worship ${ }^{(5)}$, the Prophet said in between people who doing work, God loves those who care, and the work must be done in a professional manner: if any work not given to the expert, then wait for its demise. Work must be done systematically and ina short time. ${ }^{(6)}$ Work must be based on the profit motive and achievement motive of 'Lillahi Taala'. This is accompanied by the assurance of God that he has set fortune every creature he created.

A good Muslim is that take into account in a balanced world and the hereafter. It is not a good Muslim, they were leaving for the sake of world affairs hereafter, also left hereafter to world affairs. Work and prayer are equal, if not pray is a sin, then it does not work too is a sin, if prayer should 'khusyu', then work must also be qualified. ${ }^{(7)}$

Balancing the aspects of the world and the hereafter is a unique characteristic of the Islamic economic system. A blend of material and spiritual element is not found in any other economic system, whether capitalist or socialist. There is no doubting the role of the capitalist system in production efficiency. The role of the socialist system in an effort economic equalization is very valuable. However, both 
systems have ignored the spiritual fulfillment of the indispensable man.

In addition to developing strategies that can improve the work ethic of the poor through the religious motivation in the cultural dimension at the individual level, it is also necessary to increase the education at the family level in order to have the quality and mindset that look to the future. Actually, the Government has tried to reorganize and prepare a wide variety of educational policies which is expected to spur the development of human resources. Wisdom includes efforts to improve the technical skills through vocational education and skill enhancement (professionalism). The increase was among others by expanding the approach of facilities and quality of education in all sectors, as well as increased labor productivity. But unfortunately, schools and colleges are not affordable to the general public and especially the families of workers fishing communities while fulfilling their basic needs only to be in debt. Our educational universe still looked like luxury goods packaging, too fancy.

At the community level, the poverty of fishermen communities, especially fishermen, workers indicated no integration with community institutions effectively, also marginalisation from political decision making. ${ }^{(8)}$ They often get treated as objects that need to be rather than as subjects who were given a chance to develop. In the relief program launched in the new order of government and other programs is expected to be a moral movement that allows the participation of all parties, especially the poor themselves. Poor people who are members of non-governmental groups, including the fishing communities to obtain funds as working capital to drive economic activity. Specifically, these two programs are aimed at improving the socioeconomic welfare of the poor through improvement of human resources, improving the ability of capital, business development and institutional strengthening joint efforts with the poor group.

Reality in the field of both programs can be said to be successful as evidenced by conditions of poverty that still prevails in the research location ever received funding from both programs. It is also associated with the structural dimensions of poverty that is a function of economic institutions set up to manage the funds cannot provide optimal facilities at all levels of society. So poverty is not merely dividing the aid money that involved government apparatus. More than that there should be a "realignment of economic institutions" which binds the lives of the poor in order to put the needs and aspirations of the poor, which is based on the values of the Islamic economic system.

\section{DIRECTIONS OF SOCIO-CULTURAL TRANSFORMATION OF FISHERMEN COMMUNITY}

Starting from the social position of the fishermen community who have clearly described above, where "social position" is under the influence of Sufiisme and Capitalism. Each of them gave a negative effect to the mental attitude of the people, then the only way transformation in healing the mental attitude of society is towards Islamic Rational borrowing a phrase of Nasution ${ }^{(9)}$ or by the term "freedom in complete submissiveness" or box Prophet Muhammad (10), which is an idealism (intellectual vision) that is not only concerned with spiritual aspects or 'uhrawi' but also the material aspects, precisely 'Hasanah' or Perfection Life.

The question that may arise is why the healing of the mental attitude of the people mentioned above isn't directed towards Sufiisme or toward capitalism? The answer, that rationally, they don't have a strong normative foundation. In contrast to the idealistic-Islam Rational or irrational that normatively well grounded

In Islam, the exploitation is the responsibility of the entire community, including groups involved in the exploitative practices. In reaching social change, the Qur'an itself does not raise class consciousness, but consciousness humanistic stand on egalitarianism. That is why both the exploiters and the exploited are equally responsible for the practices of an unfair system. Exploiters guilty of arrogance and power. Otherwise exploited also be guilty if they are just silent no effort to remove it from the system of exploitation. If this happens, it is feared exploiting status quo will continue and the exploited will be brought into the engineering of the exploiters. This is seen in fishing communities studied.

Meanwhile Sufism emerged in classical antiquity, the Middle Ages developed into the Order. Sufism congregation is an organization founded disciples and followers of the great Sufi certain to preserve the teachings of Sufi concerned. If Sufism in classical times patterned individually, then in the Middle Ages - through orders - Sufism turns into patterned mass. Because it's not just that the teachings of Sufi mysticism, but also ordinary people trying to run it.

The Sufis goal is to get closer to God, then they prefer the spiritual life rather than material life. In close to God, they did fast and as far as possible to leave the material pleasures. The world is left to be able to meet the Lord. This attitude is emulated by a layman, then developed in community life orientation are more inclined to the afterlife. They are not concerned with earthly life.

In addition to the hereafter orientation, the closer to God, the Sufis patiently waits and trust God's grace to be accepted come close to him. They merely reproduce the work of worship, Recitation and remember God. Such an attitude affects people in general, then among them are more concerned with the attitude of the spiritual life and the attitude of trust and wait patiently for the arrival of the grace of God. This attitude is reinforced by the lay among schools of theology of fatalism with the absolute will of God. The attitude of trust in the congregation and a fatalistic attitude in the theology of the absolute will of God made people to be static in the face of life on earth. They waited with resignation and patiently wait for God's fate is determined for them. They had little activity in the face of life in this world. 


\section{CONCLUSION}

For that, priority on the dimensions of cultural poverty in an attempt socio-cultural transformation of fishermen community towards the interests of the development is a strategy that can improve the work ethic of the poor through the "religious motivation" that is based on the Theology of the laws with rational thinking, philosophical, and scientific or 'Qadariyah' missing from the Islamic world to replace the will of the Absolute God Theology (khalawatiyah or fatalism) that develops in the fishing communities. Now the religious impulses of the increased productivity of society through "the defendant development" should be improved in order to establish the intellectual vision of society that besides uhrawi affairs, the affairs of the world also have similar interests.

\section{REFERENCES:}

[1] Arifin, Ansar. The Poverty Trap and Structural Violence at PinggawaSawi Relation of Work. Jakarta: Orbit Publishing. 2014.

[2] Hamid, Abu. Syekh Yusuf: A Priest, Sufi, and Fighter. Jakarta: Yayasan Obor Indonesia. 1994.

[3] Wahab, Abdul. Inequality Life of Fishermen in City. International Journal of Academic Research Part B. Social Sciences and Humanity, Volume 6. No. 6 July 2014.

[4] Al-Qur'an dan Its Translation. Islamic Affairs Departements of Endowments, Spreading and Ershad of Saudi Arabia Kingdom. AlQur'an of Saudi Arabia: Mujamma' al Malik Fahd li Thiba'at alMushshaf asy-Syarif Medinah Munawwarah. 1415 H, 13:11.

[5] Al-Qur'an dan Its Translation. Islamic Affairs Departements of Endowments, Spreading and Ershad of Saudi Arabia Kingdom. AlQur'an of Saudi Arabia: Mujamma' al Malik Fahd li Thiba'at alMushshaf asy-Syarif Medinah Munawwarah. 1415 H, 34:37.

[6] Al-Qur'an dan Its Translation. Islamic Affairs Departements of Endowments, Spreading and Ershad of Saudi Arabia Kingdom. AlQur'an of Saudi Arabia: Mujamma' al Malik Fahd li Thiba'at alMushshaf asy-Syarif Medinah Munawwarah. 1415 H, 94:7.

[7] Al-Qur'an dan Its Translation. Islamic Affairs Departements of Endowments, Spreading and Ershad of Saudi Arabia Kingdom. AlQur'an of Saudi Arabia: Mujamma' al Malik Fahd li Thiba'at alMushshaf asy-Syarif Medinah Munawwarah. 1415 H, 62:10.

[8] Bene, Christophe and Richard M. Friend. Poverty in Small-Scale Fisheries-Old Issue, New Analysis. Journal of Progress in Development Studies. April 2011, Volume 11 No. 2, p. 114-144.

[9] Nasution, Harun. Islamic Theology: Thoughts, History, Analysis and Comparation. UI Press. 1996.

[10] Soewardi, The Agraris Transformation of Industry in Indonesia.An Sociological Approach. Paper presented at Cultural Simposium of Indonesia-Malaysia $6^{\text {th }}$, Nopember $22^{\text {nd }} 1995$ at Kebangsaan University Bangi Selangor Malaysia. 1995. 